General comments:

In the chapter include:

- Abstract (200 words max)

- 6 keywords

- ORCID number of all authors

- Short bio (150 words max of all authors.

- Reference format use APA $6^{\text {th }}$ ed. (no DOI needed) See http://www.apastyle.org/

Editors' comments of your original chapter:

NB:

This study examines work-family conflict in domains of satisfaction (job, family, life) among Italian women entrepreneurs.

Section about laws is choppy and needs better organized. Deeper editing is needed.

The figures are a bit confusing.

Consider changing title to represent chapter objective ('looking for help?' should be omitted). Study demonstrates that social and cultural expectations do affect the wellbeing of women entrepreneurs.

EE:

Revise Reference for typos and inconsistencies.

KK:

- Interesting topic on Work-Family Conflict that affects wellbeing of women entrepreneurs.

- Given the book objectives to reach a global audience beyond academics, would enhance discussion to use descriptive stats and avoid inferential analysis.

- Explain results clearly in the text to make the chapter shorter, stronger and easier to read.

- Figures are rather hard to read and follow.

NP:

- PCA and Factor analysis are two fundamentally different methods.

- Rich chapter and analysis.

- Clear operationalization.

- English editing and style are required. 
MTL:

- I follow editors' recommendations and edit considering them and making English and style adjustment to meet objectives of our publisher Routledge and Human Center Management Book Series.

- My purpose is to help improve format, not to change context. So when authors review this "clean" edition, compare with your original and concentrate on contexts.

- As per editors recommendations to reach a broad audience I have advanced transformation from inferential to descriptive analysis to match book requirement. In this way authors are free to submit inferential analysis to a journal without requesting permissions but with the antecedent of a preview publication in this book.

- Review tables to facilitate reading.

- Very interesting study of factors that challenge work-family balance and wellbeing of women entrepreneurs. Their experience can be extrapolated to all countries Latin cultures.

- Specific comments on right margin.

Please revise and return your final version to me at your promptest convenience and not later than October 19, 2018. We have a November deadline with Routledge and before submission editors need to make final review of this $\mathbf{5 0 0}$ pages book. 


\section{Work-family conflicts and satisfaction among Italian women entrepreneurs.}

\section{Short Bio}

\section{Luisa De Vita (PhD)}

Luisa is Assistant Professor in economic sociology at Sapienza, University of Rome. She currently teaches post-graduate courses on Sociology of Oganization and Labour Market and Equal Opportunity Policies. Her main research interests are the analysis of equal opportunity, labour market policies and work life balance strategies. She is involved in several research projects for the analysis of individual trajectories of women in non-traditional paths of employment with specific attention to entrepreneurship and careers in science (STEM disciplines). Her publications appear on various journals, such as: International Journal of Sociology and Social Policy, European Management Journal, International Entrepreneurship and Management Journal, International Journal of Entrepreneurship and Innovation, Management Decision.

Orcid:orcid.org/0000-0003-4991-1676

\section{Michela Mari (PhD)}

Michela is Assistant Professor in Management at the "Tor Vergata" University of Rome, Department of Management and Law. She currently teaches post-graduate courses on General Management and Service Management. Her research interests mainly lie in the fields of: female entrepreneurship and service management. Her works appear on various outlets, such as, European Management Journal, International Entrepreneurship and Management Journal, International Journal of Entrepreneurship and Innovation, International Journal of Globalisation and Small Business, Management Decision, The Service Industries Journal.

Orcid: orcid.org/0000-0003-1404-6504

\section{Sara Poggesi (PhD)}

Sara is Associate Professor in Management at Tor Vergata University, Department of Management and Law. Her research interests mainly lie in the fields of: female entrepreneurship, service management and organizational behavior. Her works appear on various outlets, such as: European 
Management Journal, Journal of Management and Governance, Journal of Management Development, Journal of Management History, International Entrepreneurship and Management Journal, International Journal of Public Administration, International Journal of Globalisation and Small Business, International Journal of Business \& Economics, International Journal of Management, International Journal of Entrepreneurship and Innovation, Management Decision, Service Industries Journal.

Orcid: orcid.org/0000-0001-7921-8755

\begin{abstract}
The purpose of this chapter is to add knowledge to the still under-investigated relationship between the work-family conflict (WFC) and the overall level of wellbeing pursued by women entrepreneurs.

WFC, in particular, may start because work responsibilities interfere with family responsibilities (WIF) and/or when family responsibilities interfere with work demands (FIW). In this study we study if and how WIF and FIW affect women entrepreneurs' wellbeing. In doing so, a validated questionnaire was administered to 511 women entrepreneurs in Italy.

Results show that the conflict between work and family is a key aspect able to affect the overall wellbeing of women entrepreneurs. Data provide evidence that Italian women entrepreneurs present some peculiarities which reflect the national socio-economic environment.

The experienced conflicts faced by the 511 interviewed women are strongly connected both to their family sphere (FIW) and to their working loads (WIF). This "double burden" helps explaining why Italian women entrepreneurs experience more difficulties in keeping working and private lives separate and both under control, leading to higher levels of conflict, stress and lower level of life satisfaction, hindering their overall level of wellbeing.
\end{abstract}

Keywords: women entrepreneurs, work family conflict, wellbeing, life satisfaction, family satisfaction, job satisfaction

\title{
Introduction
}


The key contribution of women entrepreneurs to the socio-economic development of nations is widely recognized and, from an academic perspective, women entrepreneurship is increasingly investigated. Scholars are focusing on a widely variety of issues including women's motivations (e.g. Langowitz and Minniti, 2007; Kirkwood, 2009; Kariv, 2011), business finances (e.g. Kon and Storey, 2003; Orser et al., 2006; Wilson et al., 2007; BeckerBlease and Sohl, 2007, 2011) business performance (e.g. Rosa et al., 1996; Du Rietz and Henrekson, 2000; Fairlie and Robb, 2009; Marlow and McAdam, 2013; Powell and Eddleston, 2013), characteristics of entrepreneurs (DeMartino and Barbato, 2003; Kirkwood and Tootell, 2008; Malach-Pines and Schwartz, 2008), work-family balance (Jennings and McDougald, 2007; Parasuraman et al., 1996; Parasuraman and Simmers, 2001; Poggesi et al., 2015 and 2017), networking (Foss, 2017). But there are still few studies that address the work-life balance and the conflicts that affect the overall wellbeing of women entrepreneurs.

This chapter aims to bridge this gap. We analyze how work-family conflicts (WFC) affect women entrepreneurs' levels of job, family and life satisfaction - the three indicators of well-being examined in this work. Work-family conflict occurs when work and family demands are in conflict. Conflict may start because work responsibilities interfere with family responsibilities (WIF) or/and when family responsibilities interfere with work demands (FIW).

We study if and how WIF and FIW affect women entrepreneurs' wellbeing conducting a questionnaire that was completed by 511 Italian women entrepreneurs. Italy was selected because, on average, the number of women undertaking self-employment is higher than in other European countries (OECD, 2017). This is the result of two different reasons. Firstly, women in Italy face more difficulties in finding satisfying employment opportunities or overcoming issues related to the so-called "glass-ceiling" phenomenon; secondly, Italy shows less gender equality in the division between domestic and family roles than other European countries and lack of adequate and affordable public services. In view of these constraints, opening a business presents a good opportunity for Italian women to contemporarily work, take care of family and attain personal and professional satisfaction. However, Parasuraman and Simmers (2001) clearly claim that "entrepreneurship is not a panacea" to achieve unequivocal work - family balance because 
of the long working hours, and the stress related to the huge amount of work responsibilities that women entrepreneurs have to manage.

\section{Family and women in entrepreneurship}

Bruni et al. (2004) have stated that "family is the intervening variable between gender and entrepreneurship". Accordingly, we can identify the main family' influences on women entrepreneurship.

The role of family is pivotal for women who decide to become entrepreneurs. For a long time, scholars have pointed out the key role of the necessity driven factors that push women (and less men) into entrepreneurship to find work options, a source of income and more flexibility to balance work and family responsibilities (Marlow and Carter, 2004; DeMartino et al., 2006; McGowan et al., 2012). At this point it is relevant to refer to the well-known paper by DeMartino and Barbato (2003) which analyses women and men entrepreneurs with similar backgrounds, demographics, timing and age of their businesses to observe that the most important career motivators between them are different: women entrepreneurs prefer a career that guarantees flexibility and work-family balance, whilst men prefer a career that allows them to create wealth.

However, necessity factors are not the only motives pushing women into the entrepreneurial path. Indeed, women can be also pulled into entrepreneurship. According to GEM, “opportunity entrepreneurs" are pulled to entrepreneurship by opportunity and because they desire independence or to increase their income.

Scholars do not converge yet on which factors prevail over the others. The main reason seems to be that the push and pull motives are rarely unrelated as to exclude each other (Kirkwood, 2009; Mari et al., 2016).

Moreover, family also affects how women manage their businesses compared with men. Although introduced by Aldrich and Cliff (2003), "the family embeddedness perspective" has its roots in women entrepreneurship research (Jennings and Brush, 2013) where worth mentioning is the concept of "integrated perspective" among family, community and business characterized 
by the fact that "women perceive their businesses as 'cooperative networks of relationships' rather than separate economic units" (Brush, 1992). From Brush's perspective "business relationships are integrated instead of separated from family, societal, and personal relationships" (p. 16). More recently, the prevalent idea of the strong family role in women entrepreneurs' experience is enhanced in the " $5 \mathrm{M}$ framework" (Brush et al., 2009). This framework presents two new dimensions respect to the "3M" (Bates et al., 2007): the "motherhood" construct, at the center of the model, and "macro/meso environment" factors, focused on expectations about society and cultural norms, regional support, policies, services and initiatives. The rationale is that the nature and effects of family on women entrepreneurs vary across institutional, societal and cultural contexts (Jennings and Brush, 2013).

The degree of family embeddedness of women entrepreneurs is important because it affects motivation, economic and non-economic goals, performance measures, and training needs (Jennings and Brush, 2013). Furthermore, women who choose to pursue entrepreneurship often experience work-family conflict (WFC), defined in the employment literature as "a form of interrole conflict in which the role pressures from the work and family domains can be incompatible" (Greenhaus and Beutell, 1985). WFC is cited as a factor able to influence size and performance of women-led firms (Lee Siew Kim and Seow Ling, 2001; Loscocco and Bird, 2012; Shelton, 2006), the well-being of the entrepreneur (Shelton, 2006), and the woman's satisfaction with her job, marriage, and life (Lee Siew Kim and Seow Ling, 2001). However, studies that empirically evaluate the consequences of WFC experienced by women entrepreneurs are not very frequent yet.

\section{Effects of work- family conflict on wellbeing}

The institutional salaried employment literature emphasizes two dimensions of WFC, that, although related, deserve separate analysis: (a) work-family conflict (WIF) experienced when work interferes with family life, and (b) family-work conflict (FIW) experienced when family life interferes with work (Netemeyer et al., 1996; Gutek et al., 1991; Frone et al., 1992). WIF conflict occurs when a person experiences a high level of work pressures which negatively interferes with his/her performance in the family domain. FIW conflict occurs when a person 
experiences high level of family pressures that negatively interferes with his/her performance in the family domain (Byron, 2005; Mesmer-Magnus and Viswesvaran, 2005).

Literature on salaried employment pays attention on WFC and its dimensions because it has been linked to work performance in terms of absenteeism (e.g. Hammer et al., 2003), turnover (e.g. Good et al., 1996), lack of organizational commitment (e.g. Lyness and Thompson, 1997), and burnout. Moreover, research findings also show that WFC is related to low levels of job satisfaction (e.g. Allen et al., 2000), family satisfaction (e.g. Frone et al., 1994), and life satisfaction (e.g. Kossek and Ozeki 1998).

In this chapter our focus is to analyze the relationships between WFC and wellbeing; in particular, three indicators of wellbeing in work and family domains are examined:

- Job satisfaction, defined as personal satisfaction with various aspects of career progress and success (Parasuraman et al., 1996, p. 283).

- Life satisfaction (or the individual's quality of life), that includes physical and material wellbeing, interpersonal relations, social activities, personal development, fulfillment and recreation (Johansson and Bernspång, 2003).

- Family satisfaction, defined as the level of happiness and fulfillment with each other perceived by family members (Olson, 2004).

Although literature on salaried employment has extensively examined the relationship between WIF and FIW and wellbeing, in the women entrepreneurship literature the problem has not received due attention yet.

\section{Women entrepreneurship in Italy}

The Italian women entrepreneurship is a topic of particular interest for the country' socioeconomic context characteristics. Italy, indeed, belongs to those countries characterized by the so-called Mediterranean Welfare (Bettio and Plantenga, 2004; Naldini, 2004), meaning that it is characterized by a strong gender division of labour in the family and high structural barriers. Although gender division of labour in the family is common around the world, in Italy it has some peculiar characteristics. Table 1 shows Italy among countries scoring the highest level of 
inequality in terms of unpaid work, analyzed by sex. Worse than Italy, among EU countries, performs Portugal. 
Table 1 - Time spent in paid and unpaid work by sex in a sample of OECD developed and developing countries.

\begin{tabular}{|c|c|c|c|c|c|c|c|}
\hline & \multicolumn{2}{|c|}{$\begin{array}{l}\text { Time spent in } \\
\text { unpaid work by } \\
\text { sex }\end{array}$} & \multirow[b]{2}{*}{ Gender gap } & \multicolumn{2}{|c|}{$\begin{array}{l}\text { Time spent in paid } \\
\text { work by sex }\end{array}$} & \multicolumn{2}{|c|}{$\begin{array}{l}\text { Time spent in paid } \\
\text { and unpaid total } \\
\text { work by sex }\end{array}$} \\
\hline & Men & Women & & Men & Women & Men & Women \\
\hline & \multicolumn{2}{|c|}{ Hours per day } & & \multicolumn{2}{|c|}{ Hours per day } & \multicolumn{2}{|c|}{ Hours per day } \\
\hline \multicolumn{8}{|l|}{ Country } \\
\hline Sweden & 2.57 & 3.44 & 0.88 & 5.37 & 4.48 & 7.93 & 7.92 \\
\hline Denmark & 3.10 & 4.05 & 0.95 & 4.34 & 3.24 & 7.44 & 7.29 \\
\hline Norway & 2.81 & 3.79 & 0.98 & 4.62 & 3.33 & 7.43 & 7.12 \\
\hline Canada & 2.47 & 3.73 & 1.26 & 5.68 & 4.47 & 8.15 & 8.20 \\
\hline Finland & 2.63 & 3.93 & 1.31 & 4.14 & 3.50 & 6.77 & 7.43 \\
\hline Belgium & 2.79 & 4.18 & 1.39 & 3.70 & 2.65 & 6.49 & 6.83 \\
\hline Estonia & 2.67 & 4.15 & 1.48 & 4.40 & 4.08 & 7.07 & 8.24 \\
\hline France & 2.25 & 3.73 & 1.49 & 3.92 & 2.92 & 6.17 & 6.66 \\
\hline Germany & 2.51 & 4.04 & 1.53 & 4.83 & 3.43 & 7.33 & 7.46 \\
\hline United States & 2.50 & 4.05 & 1.55 & 5.58 & 4.09 & 8.09 & 8.15 \\
\hline United Kingdom & 2.34 & 4.14 & 1.81 & 5.14 & 3.60 & 7.48 & 7.75 \\
\hline Slovenia & 2.78 & 4.77 & 2.00 & 5.00 & 3.90 & 7.77 & 8.67 \\
\hline Netherlands & 2.22 & 4.24 & 2.02 & 5.90 & 3.43 & 8.11 & 7.66 \\
\hline New Zealand & 2.35 & 4.40 & 2.05 & 5.63 & 3.42 & 7.98 & 7.82 \\
\hline Latvia & 2.16 & 4.22 & 2.06 & 6.28 & 4.81 & 8.45 & 9.03 \\
\hline Poland & 2.65 & 4.77 & 2.12 & 4.60 & 2.69 & 7.26 & 7.46 \\
\hline Austria & 2.26 & 4.49 & 2.23 & 6.08 & 4.15 & 8.34 & 8.63 \\
\hline Australia & 2.86 & 5.18 & 2.32 & 5.07 & 2.87 & 7.93 & 8.05 \\
\hline Hungary & 2.12 & 4.47 & 2.35 & 5.45 & 3.87 & 7.57 & 8.33 \\
\hline Spain & 2.43 & 4.82 & 2.39 & 3.94 & 2.78 & 6.37 & 7.60 \\
\hline Greece & 1.82 & 4.43 & 2.62 & 3.77 & 2.41 & 5.58 & 6.84 \\
\hline Ireland & 2.15 & 4.94 & 2.78 & 5.73 & 3.29 & 7.89 & 8.22 \\
\hline Italy & 2.18 & 5.11 & 2.93 & 3.68 & 2.22 & 5.86 & 7.33 \\
\hline Korea & 0.75 & 3.79 & 3.04 & 7.03 & 4.56 & 7.78 & 8.34 \\
\hline Japan & 0.68 & 3.74 & 3.06 & 7.53 & 4.53 & 8.21 & 8.26 \\
\hline Turkey & 1.42 & 5.15 & 3.73 & 4.74 & 1.94 & 6.16 & 7.09 \\
\hline
\end{tabular}




\begin{tabular}{|l|l|l|l|l|l|l|l|l|}
\hline \multicolumn{2}{|l|}{ Portugal } & 1.61 & 5.47 & 3.87 & 6.21 & 3.86 & 7.81 & 9.32 \\
\hline \multicolumn{2}{|l|}{ Mexico } & 2.28 & 6.39 & 4.11 & 8.10 & 4.17 & 10.38 & 10.56 \\
\hline \multirow{2}{*}{$\begin{array}{l}\text { Non-OECD } \\
\text { Economies }\end{array}$} & $\begin{array}{l}\text { China } \\
\text { (People's } \\
\text { Republic } \\
\text { of) }\end{array}$ & 1.52 & 3.90 & 2.38 & 6.50 & 4.85 & 8.02 & 8.75 \\
\cline { 2 - 10 } & $\begin{array}{l}\text { South } \\
\text { Africa }\end{array}$ & 1.72 & 4.16 & 2.45 & 4.90 & 3.25 & 6.62 & 7.41 \\
\cline { 2 - 10 } & India & 0.86 & 5.87 & 5.00 & 6.51 & 3.08 & 7.37 & 8.94 \\
\hline
\end{tabular}

Source: OECD, 2017.

Data in Table 1 can be read focusing on social norms or structural barriers. According to social norms, Italy and other Southern European countries are still considered male breadwinner family models (Lewis, 1992; Trifiletti, 1999; Naldini, 2004). According to this model, men are recognized as the main breadwinner, while women's main role is as caregivers and mothers.

Female caregiving is often perceived as a mandatory duty largely due to the limited provision of care services by the State. Public spending on social services, such as care for the elderly and disabled, health, childcare, housing assistance and other, in Italy is indeed lower than the OECD average (OECD, 2017). For example, only 24 percent of Italian children up to three years are enrolled in formal childcare versus the OECD average of 33 percent (OECD, 2017). Parental leave periods are often granted only to mothers, so the families of origin - grandparents and other relatives - are still playing a relevant "role of replacement", by supporting women as informal caregivers.

Regarding public elderly care services, the situation seems even worse than public childcare (Naldini et al., 2014) to the point that about 14 percent of working women with elderly care responsibilities have to take the decision to reduce paid work or to quit their jobs to care of their relatives (European Commission, 2017).

Accordingly, the following data are not unexpected. In 2017, the employment rate of single women between 25 and 49 years is 81 percent, but it decreases drastically for married 
women, standing at 71 for women without children and 56 percent for with children (ISTAT, 2017). Only in other seven OECD countries (Chile, Greece, Hungary, Mexico, the Slovak Republic, Spain, and Turkey) the employment rate for women with children is less than $60 \%$ (OECD, 2016). Conversely, in countries as Austria, Denmark, Sweden or Switzerland more than 75 percent of mothers with children aged 0-14 are in work, with rates particularly high - at around $82-83 \%$ - in Denmark and Sweden.

The comparison of Italy with other economies can be made recurring to different international reports.

At the global level, the Global Gender Gap (GGG), published by the World Economic Forum (WEF), publishes yearly records of gaps between women and men across four key factors: i) economic participation and opportunity; ii) political empowerment; iii) educational attainment; and $i v$ ) health and survival ${ }^{1}$. The 2017 data classify Western Europe nations among those with the highest performance in the Index with an average gender gap of 25 percent. Among the best in the Region are Iceland, Norway, Finland and Sweden and among the worst in gender gaps are Greece, Italy, Cyprus and Malta. In 2017 Italy ranks 82 ${ }^{\text {nd }}$ place among 144 countries with a gender gap of over 30 percent for the first time since 2014.

The Global Entrepreneurship Monitor (GEM) initiative, launched by the World Economic Forum in 1999, is focused on the entrepreneurial activity around the world and links it to the economic and growth with the purpose to expedite policy actions. Early-Stage Entrepreneurial Activity (TEA) is one of the most important GEM indicators. It measures the share of the active population who are new entrepreneurs and leading new businesses. GEM shows that in 2016 Italy had a TEA of 4.4 percent, one of the lowest among developed countries. Italy shows the second lowest male TEA in Europe with almost 6 percent and the women TEA is 3 percent.

\footnotetext{
${ }^{1}$ WEF. Global Gender Gap Index 2017 https://www.weforum.org/reports/the-global-gender-gap-report-2017
} 
The Female Entrepreneurship Index (FEI) is indicative of a country's current situation in comparison to other countries with respect to those conditions able to fuel high potential female entrepreneurship development. This index is based on 15 pillars: Opportunity Perception; Startup Skills; Willingness and Risk; Networking; Cultural Support; Opportunity Start up; Technology Sector; Quality of Human Capital; Competition; Gender gaps; Product Innovation; Process Innovation; High Growth; Internationalization; External Financing. According to this index, Italy is in $30^{\text {th }}$ place out of 77 countries with a score of $51 \%$. The pillar in which the country shows the lowest score is Opportunity Recognition while the highest is Executive Status (in the pillars: Cultural Support).

The European Commission (2017) reports that in 2016 Italy showed among the lowest value in women employment rate (52 percent), and the second highest in the gender employment gap (20 percent). Regarding self-employed data, Italy showed one of the highest level for women (16 percent) and for men (27\%). Table 3 shows data for a selection of European countries.

Table 3 - Employment rate and entrepreneurship employment

\begin{tabular}{|c|c|c|c|c|c|}
\hline & $\begin{array}{c}\text { Women's } \\
\text { employment } \\
\text { (\% age 20-64) }\end{array}$ & $\begin{array}{c}\text { Men's } \\
\text { employment } \\
\text { (\% age 20-64) }\end{array}$ & $\begin{array}{c}\text { Gender } \\
\text { employment gap } \\
\text { (\% age 20-64) }\end{array}$ & $\begin{array}{c}\text { Women self- } \\
\text { employed } \\
\text { (\% total } \\
\text { employment) }\end{array}$ & $\begin{array}{c}\text { Men } \\
\text { self-employed } \\
(\% \text { total } \\
\text { employment })\end{array}$ \\
\hline Europe 28 & 65.3 & 76.9 & 11.6 & 10.3 & 18.5 \\
\hline Italy & 51.6 & 71.7 & 20.1 & 16.3 & 27.1 \\
\hline Greece & 46.8 & 65.8 & 19 & 23.7 & 34.9 \\
\hline Finland & 71.7 & 75.0 & 3.3 & 8.9 & 17.8 \\
\hline Sweden & 79.2 & 83.0 & 3.8 & 5.8 & 13.3 \\
\hline Germany & 74.5 & 82.8 & 8.3 & 7.1 & 12.6 \\
\hline Spain & 58.1 & 69.6 & 11.5 & 12.1 & 20.1 \\
\hline France & 66.8 & 74.2 & 7.4 & 7.8 & 14.8 \\
\hline Netherlands & 71.6 & 82.6 & 11 & 12.5 & 19.7 \\
\hline Austria & 70.9 & 78.7 & 7.8 & 8.4 & 13.7 \\
\hline Portugal & 67.4 & 74.2 & 6.8 & 12.7 & 21.3 \\
\hline $\begin{array}{l}\text { United } \\
\text { Kingdom }\end{array}$ & 72.1 & 83.1 & 11 & 10.4 & 19.1 \\
\hline
\end{tabular}


Source: European Commission, 2017.

In line with our research and regarding the gender employment gap, the European Commission (2017) states (p. 33) that "Geographical differences reflect different policy mixes to reconcile work and family responsibilities. For example, suitable child care facilities are more affordable and easier to access in some Member States than in others".

Within this framework, some important actions taken by the Italian government to foster women in entrepreneurship are worth mentioning to facilitate understanding of the long tradition of actions and attentions in this regard. The milestone law that contributed to improve growth of women entrepreneurs in Italy was Law 215 passed in 1992 (Act 215/1992) entitled "Positive actions in favor of female entrepreneurship". The law identifies women small and medium-sized enterprises (SMEs) as cooperative companies or partnerships led by at least $60 \%$ of women, corporations with two-thirds of their shares and management in women's hands, or sole proprietorship companies managed by women in sectors of craftsmanship, agriculture, tourism, commerce and services. This law's aim was to promote the creation of firms led by women, to improve the entrepreneurial education and training among women entrepreneurs, to incentive their access to credit, and to support firms led by women in innovative sectors. The law established a special fund to develop national good business practices. Over the years, Law 215 has been the reference point for the promotion of women entrepreneurship.

In terms of financial support Italy, in 2000, established the Guarantee Fund, under the control of the Ministry of Economic Development for SMEs, to support firms led by women. The guarantee does not charge commission, covers up to $80 \%$ of loans for a top amount of $€ 2.5$ million. This compares favorably with loans that guarantee up to $60 \%$ and may charge commission.

In March 2013, Decree 145/2013 (called "Piano Destinazione Italia"), converted into Law 9/2014 (art.2), and the Italian government reserved a special section of the Central Guarantee Fund ( $€ 20$ million) to support women start-ups and firms in securing bank financing. In 2016 legislative provisions on self-employment for young people were extended to include 
women with no age limits. The benefits are granted on the basis of an evaluation and up to $€ 200,000$ max. The beneficiary firm must guarantee the financial coverage of the investment programmed making a financial contribution with own resources or through external financing equal to 25 percent of the total eligible sum.

Despite the initiatives to promote women entrepreneurship, a gap still exists as in 2016, there were 1.3 million Italian female owned firms (22\% of all Italian firms). Most of them were in the service sector (70\%), followed by agriculture (17\%) and manufacturing activities (13\%) (Osservatorio Unioncamere, 2016) and tended to be smaller than those led by men: 97 percent of women firms are indeed micro-firms (1 to 9 employees) against 95 percent among men led firms.

Data on the level of education of women entrepreneurs is not available in Italy. According to the Italian National Institute of Statistics (ISTAT, 2014), 24.3 percent of women have an academic degree compared with 15.6 percent of men, meaning that 1 working woman out of four has an academic degree.

\section{Data and Method}

This study intends to investigate the impact of WFC on women entrepreneurs' wellbeing. To collect data, we developed a survey that was mailed to a sample of women entrepreneurs. These women were identified with the support of a national women's entrepreneurship association. The women in the sample had to meet the following criteria: $i$ ) own at least $51 \%$ of the firm; ii) be actively involved in the business, managing daily business activities; and iii) at least one person employed in the firm in order to analyze women entrepreneurs that manage a formal structure. Approximately 1,600 women entrepreneurs were initially reached. A total of 511 responses were obtained, resulting in a $32 \%$ response rate.

Ahl 
We measured WFC using Likert scales from " $1=$ strongly disagree" to " 6 = strongly agree" (Gutek et al., 1991). We measured four items to assess WIF, like "After work, I come home too tired to do things I like to do", and four items to assess FIW, like "I'm often tired at work because things I have to do at home".

With respect to wellbeing we considered three indicators related to job, family and life satisfaction and we followed Jennings el al (2016) to measure them.

The survey also included questions about Work Time, considering six levels ranging from (l) Less than $30 \mathrm{~h}$ to (6) More than $70 \mathrm{~h}$.; Family time, based on seven levels ranging from (1) "Less than $1 \mathrm{~h}$ " to (7) "More than $6 \mathrm{~h}$ "; Marital status, if the woman entrepreneur is married or has a partner, or she is single; Number of children, included no children, 1 child and more than one children; Age, anchored in 3 cohorts: 27-34", 35-50" and over 50"; Education level, included university, with undergraduate or graduate degrees, and secondary or high school.

\section{Results}

Results show that, in terms of age, 49 percent of the women entrepreneurs who participated in the study are 50 years or older and 19 percent are under 40.52 percent of the women had secondary education ,30 percent had undergraduate academic degrees and 10 percent Master's or PhDs. 74 percent of the women were married and 72 percent had one or more children.

In terms of regional distribution, we found high concentration of firms in the North of Italy: 68 percent compared to 11 percent of firms located in the South.

With respect to work and family involvement, the sample consists of female entrepreneurs who declare medium-high levels of involvement. The source of greater involvement is certainly the family: if, indeed, only 22 per cent of the sample declares high levels of work involvement, the percentage of women entrepreneurs strongly involved in family dynamics rises to 44 . 
Responses to wellbeing questions showed that most women report high scores in their overall levels of life satisfaction, i.e. 80 percent of them report high levels of work satisfaction and 71 percent declares high levels of family satisfaction.

To estimate how the components of the WFC are associated with the characteristics of women entrepreneurs, to their family and workloads and finally to the levels of satisfaction, we run a principal component analysis (PCA), whose preliminary results are hereafter presented

The analysis shows that the women entrepreneurs who do not experience any kind of conflict are those that we could define as "neo-entrepreneurs", who have a very young age, high levels of education and do not have children yet.

Single women entrepreneurs are, in particular, those experiencing only FIW. This result may actually be related to the high presence, in the analyzed sample, of single women entrepreneurs with children (42\%) and, therefore, this can lead to perceive as heavy the load of care with respect to work commitments.

Women entrepreneurs with the greatest loads of care (at least 1 child), who have a lower education and who have a partner are those experiencing both WIF and FIW. Interesting to point out are the differences according to the age of the sampled entrepreneurs: while women entrepreneurs aged 35-50 live as burdensome above all the interference of the family on work (FIW), for the over 50 the situation is reversed. This means that during the period in which the push to achieve professional realization is very high, family loads can be experienced as limiting professional attainment. In contrast, when the motivation for professional growth is lacking, or professional stability has been achieved, workloads are perceived as more stressful. These results are in line with previous research (Aryee et al., 2005) that claims the need to refer to the different phases of the life cycle when studying the needs of work-life conflicts, because these strongly change in relation to the different phases of life.

The performed analysis also shows that a no-conflict situation - i.e. low levels of both WIF and FIW - emerges when the time dedicated to the family and to work are low. In this 
situation, the level of life satisfaction is high. These results confirm the validity of the WFC because they mean that low levels of both WIF and FIW are associated with high levels of life satisfaction and, therefore, well-being.

In relation to satisfaction, obviously family and work satisfaction depend on other elements that are not related to WIF and FIW. When life satisfaction is taken into consideration, its low level emerges from the analysis. These data are related to women entrepreneurs who show high levels of time involvement in their work and, especially, in the family and therefore consider important for personal realization not only their work but also the family ties. Notwithstanding, the double full-time presence not only leads to high WIF but also to low levels of life satisfaction.

Moreover, the higher values of WIF with respect to FIW seem to suggest, on the one hand, that women entrepreneurs have to deal alone with the management of the different aspects of their business; on the other hand, that the possibilities to delegate the domestic and care loads are very limited. Indeed, from the analyzed surveys it emerges that most of the entrepreneurs use informal aid (i.e. grandparents) for home management. The limited availability of formal care services contributes to reinforce the model based on the central role of women and their nonsubstitutability in the family.

\section{Conclusion}

The purpose of this chapter was to add knowledge to the still under-investigated relationship between WFC experienced by women entrepreneurs and their level of wellbeing, focusing the experience of 511 Italian women. Results show that the conflict between work and family is a key aspect able to affect the overall wellbeing of women entrepreneurs. Data provide evidence that Italian women entrepreneurs present some peculiarities which reflect the national socio-economic environment. The experienced conflicts faced by the 511 interviewed women are strongly connected both to their family sphere (FIW) and to their working loads (WIF). This “double burden" helps explaining why Italian women entrepreneurs experience more difficulties in keeping working and private lives separate and both under control, leading to higher levels of conflict, stress and lower level of life satisfaction, hindering wellbeing. It is necessary to point 
out that this situation is exacerbated if we consider that, in the case of Italy, the paucity of public and private services available for women makes the possibility of delegating the domestic and care loads very limited. Moreover, the central role of women in Italian families and their essential caregiving role further hinder women's possibilities to balance family and work in general and for women entrepreneurs in particular, limiting their level of life satisfaction.

It seems that in other countries of the EU the situation is mitigated thanks, on the one hand, to a more effective public welfare system and, on the other hand, to higher gender equality.

Our findings offer suggestions for policy interventions to develop a within a win-win logic able to benefit both women entrepreneurs and the Italian socio-economic system at large.

First, policy makers and educational institutions at all levels need to devote particular attention to train women entrepreneur developing effective and comprehensive programs that meet the needs of new and experienced entrepreneurs and support them

in finding ways to manage in an effective way competing work and family demands.

Second, policy makers and the public and private sector should encourage and facilitate women's networking activities; this may offer great support to improve shortcomings of the present situation and to stimulate women business' growth.

Third, policy makers and organizations in general should devote attention to increase flexibility both in terms of working hours and in terms of childcare and elderly care services. At national level the current situation is ineffective to meet the needs of entrepreneurs in general and women entrepreneurs in particular who provide significant contribution to economic growth and sustainability and inclusive societies that converge with demands of the Knowledge Economy. 


\section{References}

Aldrich, H. E., \& Cliff, J. E. (2003). The pervasive effects of family on entrepreneurship: Toward a family embeddedness perspective. Journal of Business Venturing, 18(5), 573-596.

Allen, T. D., Herst, D. E., Bruck, C. S., \& Sutton, M. (2000). Consequences associated with workto-family conflict: a review and agenda for future research. Journal of Occupational Health Psychology, 5(2), 278.

Aryee, S., Srinivas, E. S., \& Tan, H. H. (2005). Rhythms of life: antecedents and outcomes of work-family balance in employed parents. Journal of applied psychology, 90(1), 132.

Bates, T., Jackson III, W. E., \& Johnson Jr, J. H. (2007). Advancing research on minority entrepreneurship. The Annals of the American Academy of Political and Social Science, 613(1), 10-17.

Becker-Blease, J. R., \& Sohl, J. E. (2007). Do women-owned businesses have equal access to angel capital? Journal of Business Venturing, 22(4), 503-521.

Becker-Blease, J. R., \& Sohl, J. E. (2011). The effect of gender diversity on angel group investment. Entrepreneurship Theory and Practice, 35(4), 709-733.

Bettio, F., \& Plantenga, J. (2004). Comparing care regimes in Europe. Feminist Economics, 10(1), 85-113.

Bruni, A., Gherardi, S., \& Poggio, B. (2004). Entrepreneur-mentality, gender and the study of women entrepreneurs. Journal of Organizational Change Management, 17(3), 256-268.

Brush, C. G. (1992). Research on women business owners: Past trends, a new perspective and future directions. Entrepreneurship Theory and Practice, 16(4), 5-30.

Brush, C. G., De Bruin, A., \& Welter, F. (2009). A gender-aware framework for women's entrepreneurship. International Journal of Gender and Entrepreneurship, 1(1), 8-24.

Byron, K. (2005). A meta-analytic review of work-family conflict and its antecedents. Journal of Vocational Behavior, 67(2), 169-198.

DeMartino, R., \& Barbato, R. (2003). Differences between women and men MBA entrepreneurs: exploring family flexibility and wealth creation as career motivators. Journal of Business Venturing, 18(6), 815-832.

DeMartino, R., Barbato, R., \& Jacques, P. H. (2006). Exploring the career/achievement and personal life orientation differences between entrepreneurs and nonentrepreneurs: The impact of sex and dependents. Journal of Small Business Management, 44(3), 350-368.

Du Rietz, A., \& Henrekson, M. (2000). Testing the female underperformance hypothesis. Small Business Economics, 14(1), 1-10.

European Commission (2017) "Employment and Social Developments in Europe" (Annual review, 2017

Fairlie, R. W., \& Robb, A. M. (2009). Gender differences in business performance: evidence from the Characteristics of Business Owners survey. Small Business Economics, 33(4), 375.

Foss, L. (2017). Revisiting Research On Gender In Entrepreneurial Networks. The Routledge Companion to Global Female Entrepreneurship.

Frone, M. R., Barnes, G. M., \& Farrell, M. P. (1994). Relationship of work-family conflict to substance use among employed mothers: The role of negative affect. Journal of Marriage and the Family, 56, 1019-1030. 
Frone, M. R., Russell, M., \& Cooper, M. L. (1992). Antecedents and outcomes of work-family conflict: testing a model of the work-family interface. Journal of Applied Psychology, 77(1), 65.

Global Entrepreneurship Monitor (2017/2018), “Global report”, Babson College, Babson Park, MA.

Good, L. K., Page Jr, T. J., \& Young, C. E. (1996). Assessing hierarchical differences in jobrelated attitudes and turnover among retail managers. Journal of the Academy of Marketing Science, 24(2), 148-156.

Greenhaus, J. H., \& Beutell, N. J. (1985). Sources of conflict between work and family roles. Academy of Management Review, 10(1), 76-88.

Gutek, B. A., Searle, S., \& Klepa, L. (1991). Rational versus gender role explanations for workfamily conflict. Journal of Applied Psychology, 76(4), 560.

Hammer, L. B., Bauer, T. N., \& Grandey, A. A. (2003). Work-family conflict and work-related withdrawal behaviors. Journal of Business and Psychology, 17(3), 419-436.

ISTAT, (2017) Il mercato del lavoro. Verso una lettura integrata

Jennings, J. E., \& Brush, C. G. (2013). Research on women entrepreneurs: challenges to (and from) the broader entrepreneurship literature? The Academy of Management Annals, 7(1), 663-715.

Jennings, J. E., \& McDougald, M. S. (2007). Work-family interface experiences and coping strategies: Implications for entrepreneurship research and practice. Academy of Management Review, 32(3), 747-760.

Jennings, J. E., Jennings, P. D., \& Sharifian, M. (2016). Living the dream? Assessing the "entrepreneurship as emancipation" perspective in a developed region. Entrepreneurship Theory and Practice, 40(1), 81-110.

Johansson, U., \& Bernspång, B. (2003). Life satisfaction related to work re-entry after brain injury: a longitudinal study. Brain Injury, 17(11), 991-1002.

Kariv, D. (2011). Entrepreneurial orientations of women business founders from a push/pull perspective: Canadians versus non-Canadians - A multinational assessment. Journal of Small Business \& Entrepreneurship, 24(3), 397-425.

Kirkwood, J. (2009). Motivational factors in a push-pull theory of entrepreneurship. Gender in Management: An International Journal, 24(5), 346-364.

Kirkwood, J., \& Tootell, B. (2008). Is entrepreneurship the answer to achieving work-family balance? Journal of Management \& Organization, 14(3), 285-302.

Kon, Y., \& Storey, D. J. (2003). A theory of discouraged borrowers. Small Business Economics, 21(1), 37-49.

Kossek, E., \& Ozeki, C. (1998). Work-family conflict, policies, and the job-life satisfaction relationship: A review and directions for organizational behavior-human resources research. Journal of Applied Psychology, 83(2), 139.

Langowitz, N., \& Minniti, M. (2007). The entrepreneurial propensity of women. Entrepreneurship Theory and Practice, 31(3), 341-364.

Lee Siew Kim, J., \& Seow Ling, C. (2001). Work-family conflict of women entrepreneurs in Singapore. Women in Management Review, 16(5), 204-221.

Lewis, J. (1992). Gender and the development of welfare regimes. Journal of European Social Policy, 2(3), 159-173.

Lyness, K. S., \& Thompson, D. E. (1997). Above the glass ceiling? A comparison of matched samples of female and male executives. Journal of applied psychology, 82(3), 359. 
Loscocco, K., \& Bird, S. R. (2012). Gendered paths: Why women lag behind men in small business success. Work and Occupations, 39(2), 183-219.

Malach-Pines, A., \& Schwartz, D. (2008). Now you see them, now you don't: gender differences in entrepreneurship. Journal of Managerial Psychology, 23(7), 811-832.

Mari, M., Poggesi, S., \& De Vita, L. (2016). Family embeddedness and business performance: evidences from women-owned firms. Management Decision, 54(2), 476-500.

Marlow, S., \& McAdam, M. (2013). Gender and entrepreneurship: Advancing debate and challenging myths; exploring the mystery of the under-performing female entrepreneur. International Journal of Entrepreneurial Behavior \& Research, 19(1), 114-124.

Marlow, S., \& Carter, S. (2004). Accounting for change: Professional status, gender disadvantage and self-employment. Women in Management Review, 19(1), 5-17.

McGowan, P., Redeker, C. L., Cooper, S. Y., \& Greenan, K. (2012). Female entrepreneurship and the management of business and domestic roles: Motivations, expectations and realities. Entrepreneurship \& Regional Development, 24(1-2), 53-72.

Mesmer-Magnus, J. R., \& Viswesvaran, C. (2005). Convergence between measures of work-tofamily and family-to-work conflict: A meta-analytic examination. Journal of Vocational Behavior, 67(2), 215-232.

Naldini, M. (2004). The family in the Mediterranean welfare states. Routledge.

Naldini, M., Pavolini, E., \& Solera, C. (2014). Does caring for the elderly affect mid-life women's employment? Differences across regimes. Carlo Alberto Notebooks, 368, 1-15.

Netemeyer, R. G., Boles, J. S., \& McMurrian, R. (1996). Development and validation of workfamily conflict and family-work conflict scales. Journal of applied psychology, 81(4), 400.

OECD, 2017, https://stats.oecd.org/index.aspx?queryid=54757

OECD (2016), OECD Family Database, www.oecd.org/els/family/database.htm

Olson, D. H. (2004). Family Satisfaction Scale (FSS). Minneapolis: Life Innovations.

Orser, B. J., Riding, A. L., \& Manley, K. (2006). Women entrepreneurs and financial capital. Entrepreneurship Theory and Practice, 30(5), 643-665.

Parasuraman, S., \& Simmers, C. A. (2001). Type of employment, work-family conflict and wellbeing: a comparative study. Journal of Organizational Behavior: The International Journal of Industrial, Occupational and Organizational Psychology and Behavior, 22(5), 551-568.

Parasuraman, S., Purohit, Y. S., Godshalk, V. M., \& Beutell, N. J. (1996). Work and family variables, entrepreneurial career success, and psychological well-being. Journal of vocational behavior, 48(3), 275-300.

Poggesi, S., Mari, M., \& De Vita, L. (2017). Women entrepreneurs and work-family conflict: an analysis of the antecedents. International Entrepreneurship and Management Journal, 1-24.

Poggesi S., Mari M., De Vita L. (2015), "Family and work-life balance mechanisms: what is their impact on the performance of Italian female service firms?", The International Journal of Entrepreneurship and Innovation, 16(1):43-53.

Powell, G. N., \& Eddleston, K. A. (2013). Linking family-to-business enrichment and support to entrepreneurial success: do female and male entrepreneurs experience different outcomes? Journal of Business Venturing, 28(2), 261-280.

Rosa, P., Carter, S., \& Hamilton, D. (1996). Gender as a determinant of small business performance: Insights from a British study. Small Business Economics, 8(6), 463-478.

Shelton, L. M. (2006). Female entrepreneurs, work-family conflict, and venture performance: New insights into the work-family interface. Journal of Small Business Management, 44(2), 285-297. 
Trifiletti, R. (1999). Southern European welfare regimes and the worsening position of women. Journal of European Social Policy, 9(1), 49-64.

Wilson, F., Kickul, J., \& Marlino, D. (2007). Gender, Entrepreneurial Self-Efficacy, and Entrepreneurial Career Intentions: Implications for Entrepreneurship Education. Entrepreneurship Theory and Practice, 31(3), 387-406. 